\title{
Lanthanide Dithiocarbamate Complexes: Efficient Catalysts for the Cyanosilylation of Aldehydes
}

\author{
Juliana A.Vale,* Wagner M. Faustino, Paulo H. Menezes and Gilberto F. de Sá \\ Departamento de Química Fundamental, Universidade Federal de Pernambuco, 50740-540 Recife-PE, Brazil
}

Uma nova classe de complexos ditiocarbamato de lantanídeo foi usada para promover a cianosililação de aldeídos com elevados rendimentos à temperatura ambiente. Esta é a primeira aplicação de ditiocarbamato de lantanídeo atuando como ácido de Lewis.

A new class of lanthanide dithiocarbamate complexes was used to promote the cyanosilylation of aldehydes at high yields at room temperature. This represents the first application of lanthanide dithiocarbamate acting as Lewis acid.

Keywords: lanthanide dithiocarbamate, cyanosilylation, Lewis acid, cyanohydrins

\section{Introduction}

The addition of trimethylsilyl cyanide (TMSCN) to carbonyl compounds is one of the most effective preparation methods of cyanohydrins. ${ }^{1}$ Upon reaction, cyanohydrins or cyano trimethylsilyl ethers can be transformed into the corresponding $\alpha$-hydroxyacids, ${ }^{2} \alpha$-hydroxyketones, ${ }^{3} \alpha$ amino acids, ${ }^{4}$ and $\beta$-amino alcohols, ${ }^{5}$ which are not only important building blocks in the synthesis of natural products but also in the field of biology and pharmaceuticals.

Many different catalysts have been developed for this reaction. ${ }^{6}$ A range of chemical catalyst classes are available for such reaction, including chiral and achiral Lewis acids ${ }^{7}$ and bases ${ }^{8}$ and transition metal complexes. ${ }^{9}$ In recent years, several lanthanide compounds such as triflates ${ }^{10}$ and organometallic derivatives ${ }^{11}$ have been used as catalysts for the addition of TMSCN to carbonyl compounds. Additionally, optically active catalysts based on lanthanides for the asymmetric synthesis of cyanohydrins have been reported in the literature. ${ }^{12}$

We describe herein a high yield and at room temperature methodology for cyanation of aldehydes by the use of lanthanide dithiocarbamate complexes $\mathbf{1}$, an inexpensive catalyst (Figure 1).

The use of complexes $(\mathbf{1})^{13}$ has two advantages if compared to other systems based lanthanide compounds: (i) chemical stability and easy manipulation in anhydrous form; (ii) high solubility in organic solvents.

*e-mail: julianadqf@yahoo.com.br

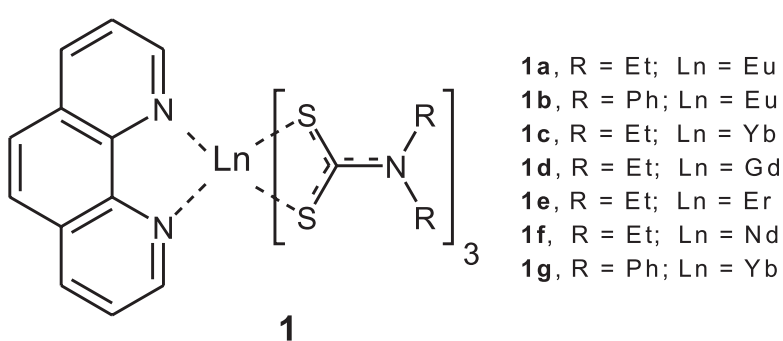

Figure 1. Lanthanide dithiocarbamate complexes.

\section{Results and Discussion}

Since our initial studies focused on the development of an optimum set of reaction conditions, the addition of TMSCN to benzaldehyde was examined in order to optimize the reaction conditions. In this way, benzaldehyde $(1.25 \mathrm{mmol})$ and TMSCN $(2.5 \mathrm{mmol})$ were treated at room temperature with different lanthanide catalysts (Table 1).

As it can be seen on Table 1, the use of $1 \mathrm{~mol} \%$ of lanthanide catalyst (1a-g) for the addition of TMSCN to benzaldehyde in THF, gave the corresponding trimethyl silyl ethers cyanohydrin (2a) at room temperature with excellent yields. Ytterbium catalyst (1c) proved to be the most effective (Table 1, entry 7). In the absence of catalyst, the reaction proceeded in longer reaction times ( 6 days at room temperature) to give product in $45 \%$ yield (Table 1, entry 13). Lengthy reaction time was observed when 1c was replaced by $\mathrm{Yb}(\mathrm{OTf})_{3}$ (Table 1, entry 12). 
It was also observed that the replacements of ethyl group in lanthanide dithiocarbamate complexes (1a and 1c, Table 1, entries 3 and 7) by the phenyl group ( $\mathbf{1 b}$ and $\mathbf{1 g}$, Table 1, entries 2 and 11) have small influence in the reaction yield.

Table 1. Addition of TMSCN to benzaldehyde catalyzed by lanthanide complexes 1 in different reaction conditions
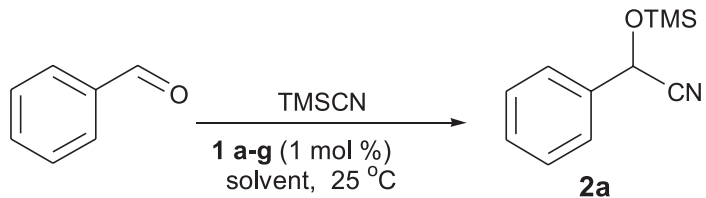

\begin{tabular}{lcccc}
\hline Entry & $\begin{array}{c}\text { Lanthanide } \\
\text { complex }\end{array}$ & Solvent & time $^{\mathrm{a} / \mathrm{h}}$ & Yield $^{\mathrm{b}} / \%$ \\
\hline 1 & $\mathbf{1 a}$ & $\mathrm{CH}_{2} \mathrm{Cl}_{2}$ & 10 & 98 \\
2 & $\mathbf{1 b}$ & $\mathrm{CH}_{2} \mathrm{Cl}_{2}$ & 10 & 87 \\
3 & $\mathbf{1 a}$ & $\mathrm{THF}$ & 9 & 98 \\
4 & $\mathbf{1 a}$ & $\mathrm{CH}_{3} \mathrm{CN}$ & 10 & 70 \\
5 & $\mathbf{1 a}$ & $\mathrm{PhCH}_{3}$ & 10 & 65 \\
6 & $\mathbf{1 a}$ & $\mathrm{CH}_{3} \mathrm{CH}_{2} \mathrm{OH}$ & 10 & - \\
7 & $\mathbf{1 c}$ & $\mathrm{THF}$ & 6 & 99 \\
8 & $\mathbf{1 d}$ & $\mathrm{THF}$ & 10 & 97 \\
9 & $\mathbf{1 e}$ & $\mathrm{THF}$ & 8 & 92 \\
10 & $\mathbf{1 f}$ & $\mathrm{THF}$ & 11 & 94 \\
11 & $\mathbf{1 g}$ & $\mathrm{THF}$ & 6 & 86 \\
12 & $\mathrm{Yb}(\mathrm{OTf})_{3}{ }^{\mathrm{c}}$ & $\mathrm{THF}$ & 20 & 93 \\
13 & - & $\mathrm{CH}_{2} \mathrm{Cl}$ & 6 days & 45 \\
\hline
\end{tabular}

${ }^{\mathrm{a}}$ The consumption of $\mathrm{PhCHO}$ was observed by TLC. ${ }^{\mathrm{b}}$ Yields refer to the isolated products. ${ }^{\mathrm{c}} 1 \mathrm{~mol} \%$ was used.

The influence and the nature of the solvent are noteworthy. When the reaction was performed using ethanol as solvent no product was observed (Table 1, entry 6). The use of acetonitrile or toluene gave the desired product in lower yields (Table 1, entries 4 and 5). On the other hand, the use of dichloromethane or tetrahydrofuran greatly enhanced the product yield.

Thus, the optimal conditions for the cyanation reaction were found to be the use of Ytterbium catalyst 1c $(1 \mathrm{~mol} \%)$ and THF as solvent at room temperature for 6 hours. Moreover, the methodology was extended to other aldehydes. The results are summarized on Table 2.

The electronic effects of the aldehyde were briefly studied. All substituted aldehydes proved to have similar reactivities giving the desired products in high yields. Similar reactivity was observed for both aldehydes containing activating or deactivating groups (Table 2, Compounds $\mathbf{2 b}-\mathbf{2 g}$ ). Acid sensitive aldehydes such as furfuraldehyde and cinnamaldehyde gave products without decomposition (Table 2, compounds $\mathbf{2 j}$ and $\mathbf{2 k}$ ). When $n$ propanal and $n$-heptanal were used as aldehyde source, the desired cyanohydrins were obtained in good yield and short reaction time (Table 2, compounds $2 \mathbf{h}$ and $\mathbf{2 i}$ ).
Table 2. Addition of TMSCN to aldehydes catalyzed by ytterbium diethyl-dithiocarbamate complex ${ }^{\mathrm{a}}(\mathbf{1 c})$

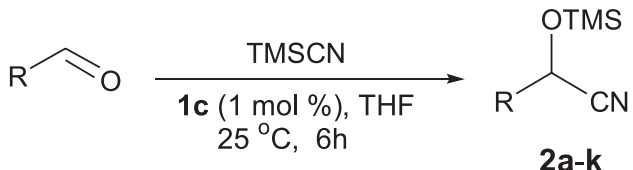

\begin{tabular}{|c|c|c|}
\hline Compound & $\mathrm{R}$ & Yield/\% \\
\hline $2 \mathbf{a}$ & Phenyl & 99 \\
\hline $2 b$ & 2-Naphthyl & 98 \\
\hline $2 c$ & $4-\mathrm{NO}_{2}-\mathrm{C}_{6} \mathrm{H}_{4}$ & 87 \\
\hline $2 d$ & $2-\mathrm{NO}_{2}-\mathrm{C}_{6} \mathrm{H}_{4}^{4}$ & 89 \\
\hline $2 e$ & $4-\mathrm{Br}^{-} \mathrm{C}_{6} \mathrm{H}_{4}$ & 95 \\
\hline $2 f$ & $4-\mathrm{Cl}-\mathrm{C}_{6} \mathrm{H}_{4}^{4}$ & 97 \\
\hline $2 \mathrm{~g}$ & 4-EtO- $\mathrm{C}_{6} \mathrm{H}_{4}^{4}$ & 98 \\
\hline $2 \mathrm{~h}$ & $\mathrm{C}_{2} \mathrm{H}_{5}{ }^{0}$ & 80 \\
\hline $2 \mathrm{i}$ & $\mathrm{C}_{6} \mathrm{H}_{13}$ & 81 \\
\hline $2 \mathrm{j}$ & $\mathrm{PhCH}=\mathrm{CH}$ & 98 \\
\hline $2 k$ & 2-Furyl & 97 \\
\hline
\end{tabular}

\section{Experimental}

\section{General methods}

All products are known and were identified by comparison of their spectral data and physical properties with authentic sample or with those reported in the literature. ${ }^{11,14-16}$ The progress of reaction was monitored by thin layer chromatography on silica gel. All yields refer to isolated products.

${ }^{1} \mathrm{H}$ NMR and ${ }^{13} \mathrm{C}$ NMR spectra were recorded on a Varian Unity Plus (300 MHz) spectrometer in $\mathrm{CDCl}_{3}$ with TMS as an internal standard. Mass spectra were obtained on a Shimadzu GC-MS QP5050A instrument operating at $70 \mathrm{EV}$.

General procedure for lanthanide complexes (1) promoted addition TMSCN to aldehydes

To a solution of ytterbium diethyldithiocarbamate complex, 1c (10 mg, $0.0125 \mathrm{mmol})$ in THF $(3 \mathrm{~mL})$ under argon at room temperature was added aldehyde $(1.25 \mathrm{mmol})$ followed by TMSCN $(2.5 \mathrm{mmol})$. The resulting solution was stirred at room temperature for 6 hours before quenching with $\mathrm{H}_{2} \mathrm{O}(3 \mathrm{~mL})$. The mixture was diluted with dichloromethane $(5 \mathrm{~mL})$ and the organic phase was separated, dried over anhydrous magnesium sulfate and concentrated in vacuum. The crude product was purified by flash chromatography eluting with $n$-hexane / ethyl acetate (8:2) to give the cianohydrin silyl ether. 


\section{Conclusions}

In conclusion, we have demonstrated the effectiveness of the use of new lanthanide complexes as Lewis acids in the addition of TMSCN to various aldehydes. The present methodology provides the first example that utilizes the lanthanide dithiocarbamate complexes acting as Lewis acid catalysts in the cyanosilylation of aldehydes to give the corresponding cyanohydrins in good yields and short reaction times if compared with other methodologies already described for lanthanide compounds.

\section{Acknowledgments}

We gratefully acknowledge the financial support from CNPq, IMMC-CNPq, FACEPE and CAPES.

\section{References}

1. Gregory, R. J. H.; Chem. Rev. 1999, 99, 3649; Duthaler, R. O.; Hafner, A.; Chem. Rev. 1992, 92, 807; North, M.; Tetrahedron: Asymmetry 2003, 14, 147; Pisoni, D. S.; Silva, D. B.; Schenato, R. A.; Ceschi, M. A.; J. Braz. Chem. Soc. 2004, 15, 652.

2. Effenberger, F.; Horsch, B.; Weingart, F.; Ziegler, T.; Kühner, S.; Tetrahedron Lett. 1991, 32, 2605; Effenberger, F.; Heid, S.; Tetrahedron: Asymmetry 1995, 6, 2945.

3. Krepski, L. R.; Jensen, K. M.; Heilmann, S. M.; Rasmussen, J. K.; Synthesis 1986, 301.

4. Zandbergen, P.; Brussee, J.; Van der Gen, A.; Kruse, C. G.; Tetrahedron: Asymmetry 1992, 3, 769.

5. Ziegler, T.; Horsch, B.; Effenberger, F.; Synthesis 1990, 575; Tanaka, K.; Mori, A.; Inoue, S.; J. Org. Chem. 1990, 55, 181; Kanerva, L. T.; Acta Chem. Scand. 1996, 50, 234.

6. Azizi, N.; Saidi, M. R.; J. Organomet. Chem. 2003, 688, 283; Jafari, A. A.; Firouzabadi, H.; Iranpoor, N.; J. Organomet. Chem. 2005, 690, 1556; Bandini, M.; Cozzi, P.; Melchiorre, P.; Ronochi, A. V.; Tetrahedron Lett. 2001, 42, 3041; Curini, M.; Epifano, F.; Marcotullio, M. C.; Rosati, O.; Rossi, M.; Synlett 2002, 315; Kim, S. S.; Kim, D. W.; Rajagopal, G.; Synthesis 2004, 213.
7. Evans, D. A.; Truesdale, L. K.; Tetrahedron Lett. 1973, 14, 4929; Loh, T. P.; Xu, K. C.; Ho, D. S. C.; Sim, K. Y. Synlett 1998, 1169; Bolm, C.; Muller, P.; Harms, K.; Acta Chem. Scand. 1996, 50, 305; Bolm, C.; Muller, P.; Tetrahedron Lett. 1995, 36, 1625; Pan, W.; Feng, X.; Gong, L.; Hu, W.; Li, Z.; Mi, A.; Jiang, Y.; Synlett 1996, 337; Belokon, Y.; Flego, M.; Ikonnikov, N.; Moscalenko, M.; North, M.; Orizu, C.; Tararov, V.; Tasinazzo, M.; J. Chem. Soc., Perkin Trans 1 1997, 1293; Tararov, V. I.; Hibbs, D. E.; Hursthouse, M. B.; Ikonnikov, N. S.; Malik, K. M. A.; North, M.; Orizu, C.; Belokon, Y. N.; J. Chem. Soc., Chem. Commun. 1998, 387; Kobayashi, S.; Tsuchiya, Y.; Mukaiyama, T.; Chem. Lett. 1991, 541; Iovel, I.; Popelis, Y.; Fleisher, M.; Lukevics, E.; Tetrahedron: Asymmetry 1997, 8, 1279; Corey, E. J.; Wang, Z.; Tetrahedron Lett. 1993, 34, 4001.

8. Fetterly, B.; Verkade, J. G.; Tetrahedron Lett. 2005, 46, 8061; Guo-Fu, Z.; J. Mol. Catal. A.: Chem. 1998, 132, 1381; Tian, S.-K.; Deng, L.; J. Am. Chem. Soc. 2001, 123, 6195; Tian, S.K.; Hong, R.; Deng, L.; J. Am. Chem. Soc. 2003, 125, 9900; Tian, S.-K.; Chen, Y.; Hang, J.; Tang, L.; Mcdaid, P.; Deng, L.; Acc. Chem. Res. 2004, 37, 621.

9. Li, Y.; He, B.; Qin, B.; Feng, X.; Zhang, G.; J. Org. Chem. 2004, 69, 7910.

10. Yang, Y.; Wang, D.; Synlett 1997, 1379.

11. Mei, L; Zhu, M. H.; Synth. Commun. 2005, 35, 2615.

12. Aspinall, H. C.; Bickey, J. F.; Greeves, N.; Kelly, R. V.; Smith, P. M.; Organometallics 2005, 24, 3458; Qian, C. T.; Zhu, C. J.; Huang, T. S.; J. Chem. Soc., Perkin Trans 1 1998, 2131; Utimoto, K.; Takai, T.; Kasuga, Y.; Matsubara, S.; Appl. Organomet. Chem. 1995, 9, 413; Yang, Y.; Wang, D.; Synlett 1997, 1379.

13. Faustino, W. M.; Malta, O. L.; Teotonio, E. E. S.; Brito, H. F.; Simas, A. M.; De Sá, G. F.; J. Phys. Chem. A. 2006, 110, 2510.

14. Mei, L.; J. Mol. Catal. A.: Chem. 2005, 227, 183.

15. Kim, S. S.; Rajagopal, G.; Song, D. H.; J. Organomet. Chem. 2004, 689, 1734.

16. Shen Y.; Feng X.; Li Y.; Zhang G.; Jiang Y.; Tetrahedron 2003, 59, 5667.

Received: June 9, 2006 Published on the web: August 1, 2006 